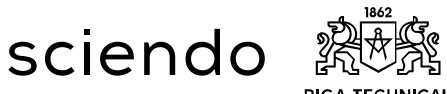

\section{REAL ESTATE ENTREPRENEURIAL TRAINING AND EDUCATION IN TERTIARY INSTITUTION: AN ANTIDOTE TO UNEMPLOYMENT}

\author{
Paul C. ANIH ${ }^{1}$, Chicheta F. NISSI ${ }^{2}$, Uduakobong E. AKPAN ${ }^{3}$ \\ 1,2,3 University of Uyo, Uyo, Nigeria \\ Corresponding author's e-mail: paulanih@uniuyo.edu.ng
}

\begin{abstract}
Real estate entrepreneurship training and education in tertiary institutions can be a source of remedy to unemployment in Nigeria. World Bank (2019) reveals that Nigeria unemployment rate was $6.03 \%$ in the year 2018 and the country ranked $83^{\text {rd }}$ with high unemployment. The aim of the research is to examine the perception and responses of undergraduates of Estate Management and Valuation on entrepreneurship training and education for professional competence. The University of Uyo was studied and particularly Estate Management undergraduates during the academic years of 2014/20152018/2019. The method of the research was a descriptive study. Data were obtained from the mean scores of the class assessments (CAs) and the examination scores (ESs) administered to the students on selected courses related to entrepreneurial education. The students' performance was used as an indicator for their willingness to adhere to entrepreneurial education in Real Estate Management and Valuation. The National Universities Commission grading scale was adopted $(\mathrm{A}=70-100 ; \mathrm{B}=60-69 ; \mathrm{C}=50-59 ; \mathrm{D}=45-49$; $\mathrm{E}=40-44 ; \mathrm{F}=0-39)$. The finding shows that the score for all the courses was above $50 \%$. The entrepreneurial study was $62 \%$, which was "B" grade of National Universities Commission scale. The study, therefore, concludes that the students of estate management were willing to adhere to entrepreneurial training and education from their scores. The study recommends the provision of adequate learning environment, qualified teaching staff and provision of technical resources.
\end{abstract}

Keywords: Entrepreneurial Education, Professional Competence, Real Estate Management, Students, Unemployment

\section{INTRODUCTION}

This study examines the prospect of entrepreneurship training and education in real estate as a dais for economic self-reliance and sustainability for graduates of tertiary institutions in Nigeria. The rationale is that real estate profession is an important economic domain that deals with human sustainability in terms of shelters as a social fundamental need for various classes of individuals and, secondly, it is a means of production for economic goods and services. With the increasing demand for better real estate goods and services, there is an urgent need for entrepreneurship as a driver for opportunities in self-reliance and socioeconomic reality. The study also assesses the perception and responses of undergraduates of estate management and valuation (University of Uyo, Nigeria) on entrepreneurial 
training and education in real estate for professional competence and competitiveness. The economic indicator in Nigeria labour sector signals red-light, suggesting danger as the state of the national economy is surrounded by the dilemma of unemployment. According to the National Bureau of Statistics (2017), the country's unemployment status increased from $14.2 \%$ to $18.8 \%$ in 2017 . This rise on unemployment situation could be linked to the rise in the Nigerian labour population from 83.9 million in the second quarter to 85.1 million in the third quarter of 2017, a disparity of 1.2 million which suggested an additional workforce (National Bureau of Statistics, 2017). In another study, Adeyemo (2018) argued that the general active labour force comprised 85.05 million people in Nigeria, while 16 million remained unemployed in the third quarter of 2017.

The objectives of the study are to assess the performance of the students on entrepreneurship course and other related subjects, to examine the challenges encountered by students of estate management in the entrepreneurial training and education and evaluate the relationship between entrepreneurship and unemployment. The study focuses on the undergraduates of estate management at the University of Uyo during the academic years of 2014/2015-2018/2019.

\section{THE CONCEPT AND EMERGENCE OF ENTREPRENEURSHIP AT THE NIGERIAN TERTIARY INSTITUTIONS}

Katila et al. (2012) and Yetisen et al. (2015) agree that "entrepreneurship entails a pattern for designing a new business that is original and which may not be large at the inception". Entrepreneurship could also be viewed as the "capacity and willingness to develop, organize and manage a business venture along with any of its risks to make a profit" (Business Dictionary, 2015; Adams, 2019). According to Adams (2019), developing entrepreneurship can be profitable and have an impact on the economy and society in several ways. He also maintains that entrepreneurship involves the routine, which comprises creativity. The operators of entrepreneurship are regarded as entrepreneurs. These entrepreneurs develop novel businesses and subsequent opportunities that open up employment, which usually generates a ripple effect, resulting in more and more development (Katila, Chen, and Piezunka, 2012 \& Yetisen et al., 2015). A major role played by entrepreneurs is to identify problems in the society and take advantage of them.

Students at the Nigerian tertiary institutions are guided on how to develop and manage businesses from the onset. Akintayo (2014) reported that "the Federal Government of Nigeria made entrepreneurial studies a compulsory program in all the universities in Nigeria". This could be explained from the perspective that undergraduates should go through the general and specific program in entrepreneurship apart from the discipline of their study. The main idea of the entrepreneurship was to help undergraduates to begin their own business alongside their chosen field of endeavour when they graduate. Adekunle and David (2014) disclosed that this reason was targeted at empowering the undergraduates of higher learning to bridge the gap of unemployment and encourage diversification in businesses and self-reliance. Falola (2009) reiterates that the prime target should continue to be the discovery through research and dissemination of new knowledge. 
The new knowledge can only be profitable to society when applied to real-world needs. Efficient entrepreneurial skill needs an optimum level of educational achievement involving both research and technification for an effective drive of the purpose(s). Almeida, De Paula, and Pessali (2014) view entrepreneurship in contemporary society as the need for human resources that could be combined to improve and develop a business prospect. Levy and Scully (2007), Khan, Munir and Willmott (2007), as well as Almeida, De Paula, and Pessali (2014) were of the same view that in market economies, entrepreneurship education was a resource that was often best accomplished when innovations were encouraged.

\subsection{Brief on the Nigerian Tertiary Education System}

UBEC (2012) and World Education Services (WES) (2017) explain that "Nigeria operates education structures that are classified into three different categories: basic education which is nine years; post-primary/senior secondary education which is three years; and tertiary education which is four to six years, depending on the program of study". Also, "at the tertiary level, the system consists of a university sector and a non-university sector. The latter is composed of polytechnics, monotechnics and colleges of education" (Jennifer, Nick, \& Caroline, 2017). Jennifer, Nick, and Caroline, explained that the tertiary sector, as a whole, offers opportunities for undergraduate, graduate, vocational and technical education. The number of Nigerian universities by groups is shown in Table 1.

Table 1. The Grouping of the Nigerian Universities (Federal, State and Private Universities) (National Universities Commission, 2019)

\begin{tabular}{ll}
\hline Grouping of the Universities & No. of Universities (2019) \\
\hline Federal Universities & 43 \\
State Universities & 52 \\
Private Universities & 79 \\
\hline \hline Total & 174 \\
\hline
\end{tabular}

Table 1 above is the stratification of the Nigerian universities by the National Universities Commission. There are 43 federal universities, 52 state universities and 79 private universities (National Universities Commission, 2019). The total number of the Universities approved by the National Universities Commission (NUC) was one hundred and seventy-four (174). The distribution of the Universities in Nigeria is shown at Figure 1. 


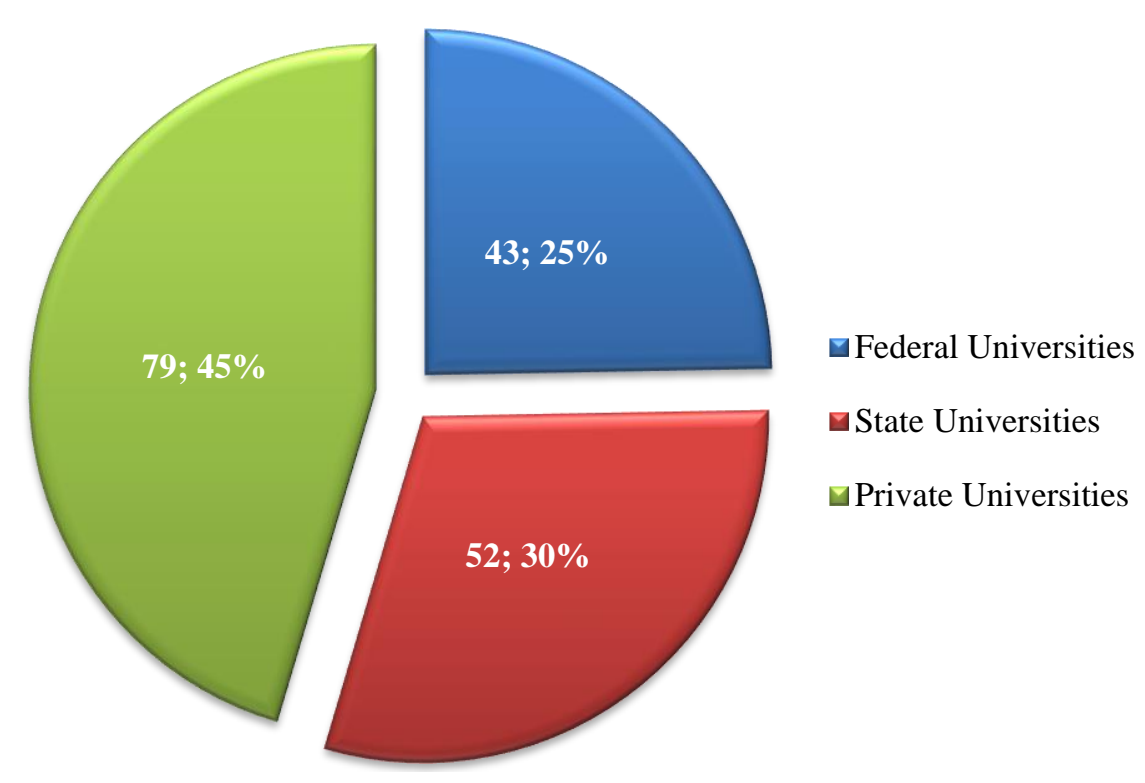

Fig. 1. The distribution of the Universities in Nigeria: the federal universities $25 \%$; the state universities $30 \%$; the private universities $45 \%$ (developed by the authors, data adapted from the National Universities Commission, 2019).

Table 2 shows the growth of the Nigerian universities comprising federal, state and private universities.

Table 2. The Growth of the Nigerian Universities from 2005-2019 (World Education Services, 2017; National Universities Commission, 2019)

\begin{tabular}{lc}
\hline Year & No of Universities \\
\hline $\mathbf{2 0 0 5}$ & 51 \\
$\mathbf{2 0 0 8}$ & 94 \\
$\mathbf{2 0 1 1}$ & 117 \\
$\mathbf{2 0 1 2}$ & 122 \\
$\mathbf{2 0 1 3}$ & 128 \\
$\mathbf{2 0 1 7}$ & 152 \\
$\mathbf{2 0 1 9}$ & 174 \\
\hline
\end{tabular}


The choice to show the growth trend from 2005 was basically to minimize the items on the table. The selection is unbiased. The data from 2005-20017 were drawn from the World Education Services (2017), while the data for 2019 were drawn from the National University Commission (2019). The Figure 2 represents the years of the growth of the Nigerian Universities from 2005-2019.

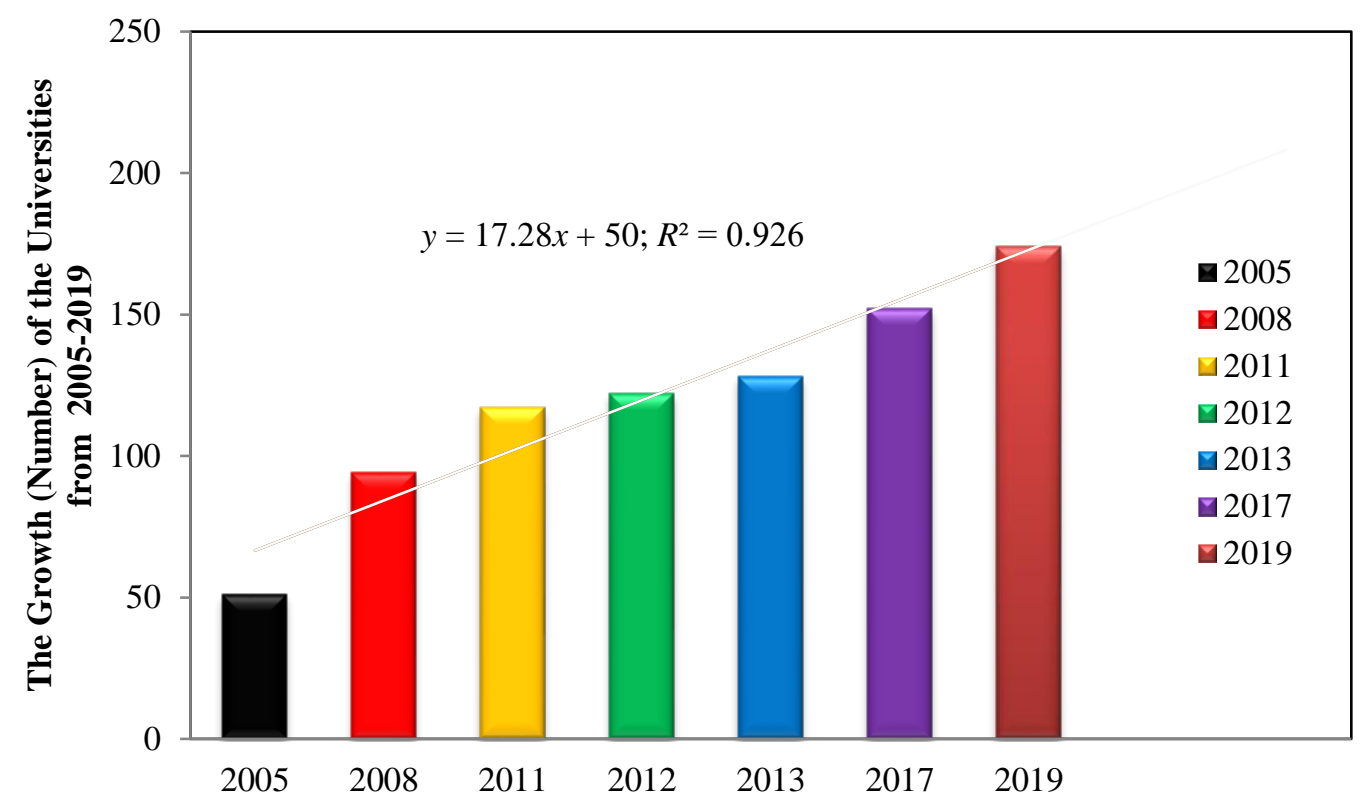

Fig. 2. The Years of the Growth of the Nigerian Universities from 2005-2019 (developed by the Authors, based on World Education Services and the National University Commission).

Figure 2 represents the column chart of the growth of the number of Nigerian Universities. It could be seen from the chart that the growth in the number of Nigerian Universities in the year after the previous year did not decline but recorded a greater number of Universities than the previous years. This also indicates the opportunities to train more entrepreneurs in Nigerian Universities.

\subsection{Employment Situation in Nigeria: The Logic for Real Estate Entrepreneurship}

According to World Bank (2019), the status of unemployment in Nigeria is high including the majority of third world nations. This is better explained by the fact that the number of unemployed in the labour market rises daily. However, considering the initiative to inculcate entrepreneurship training in the nation's tertiary institutions, the logic is aimed at creating employment opportunities to reduce the high rate of unemployment, particularly in Nigeria. The activities of realtors in the building industry such as valuation, project management and real estate investment appraisal, offer undergraduates of real estate in tertiary institutions wide opportunities to be entrepreneurs and, beyond this, to become employers of labour. In further clarification, the International Labour Organization 
(ILO) (2017) explains unemployment as the segment of the labour potentials that are not employed but are seeking for a job. The labour potentials are those who can work but they do not have the job, though involved in the search for one. They do not include people who are not looking for a job such as children and the retired. The unemployment rate in Nigeria from 1999 to 2018 is shown at Table 3.

Table 3. The Unemployment Rate in Nigeria from 1999 to 2018

(Data: World Bank, 2019)

\begin{tabular}{|c|c|c|c|}
\hline Year & $\begin{array}{c}\text { Unemployment } \\
\text { rate }\end{array}$ & Year & $\begin{array}{c}\text { Unemployment } \\
\text { rate }\end{array}$ \\
\hline $\mathbf{1 9 9 1}$ & 3.56 & $\mathbf{2 0 0 5}$ & 3.87 \\
\hline $\mathbf{1 9 9 2}$ & 3.56 & $\mathbf{2 0 0 6}$ & 3.67 \\
\hline $\mathbf{1 9 9 3}$ & 3.83 & $\mathbf{2 0 0 7}$ & 3.44 \\
\hline $\mathbf{1 9 9 4}$ & 4.02 & $\mathbf{2 0 0 8}$ & 3.42 \\
\hline $\mathbf{1 9 9 5}$ & 3.95 & $\mathbf{2 0 0 9}$ & 3.76 \\
\hline $\mathbf{1 9 9 6}$ & 3.95 & $\mathbf{2 0 1 0}$ & 3.77 \\
\hline $\mathbf{1 9 9 7}$ & 3.97 & $\mathbf{2 0 1 1}$ & 3.70 \\
\hline $\mathbf{1 9 9 8}$ & 3.99 & $\mathbf{2 0 1 2}$ & 3.69 \\
\hline $\mathbf{1 9 9 9}$ & 4.01 & $\mathbf{2 0 1 3}$ & 3.70 \\
\hline $\mathbf{2 0 0 0}$ & 3.95 & $\mathbf{2 0 1 4}$ & 4.44 \\
\hline $\mathbf{2 0 0 1}$ & 4.03 & $\mathbf{2 0 1 5}$ & 5.31 \\
\hline $\mathbf{2 0 0 2}$ & 4.11 & $\mathbf{2 0 1 6}$ & 6.24 \\
\hline $\mathbf{2 0 0 3}$ & 4.06 & $\mathbf{2 0 1 7}$ & 6.01 \\
\hline $\mathbf{2 0 0 4}$ & 3.98 & $\mathbf{2 0 1 8}$ & 6.03 \\
\hline
\end{tabular}

The visualization of unemployment rate in Nigeria from 1999 to 2018 is shown at Figure 3.

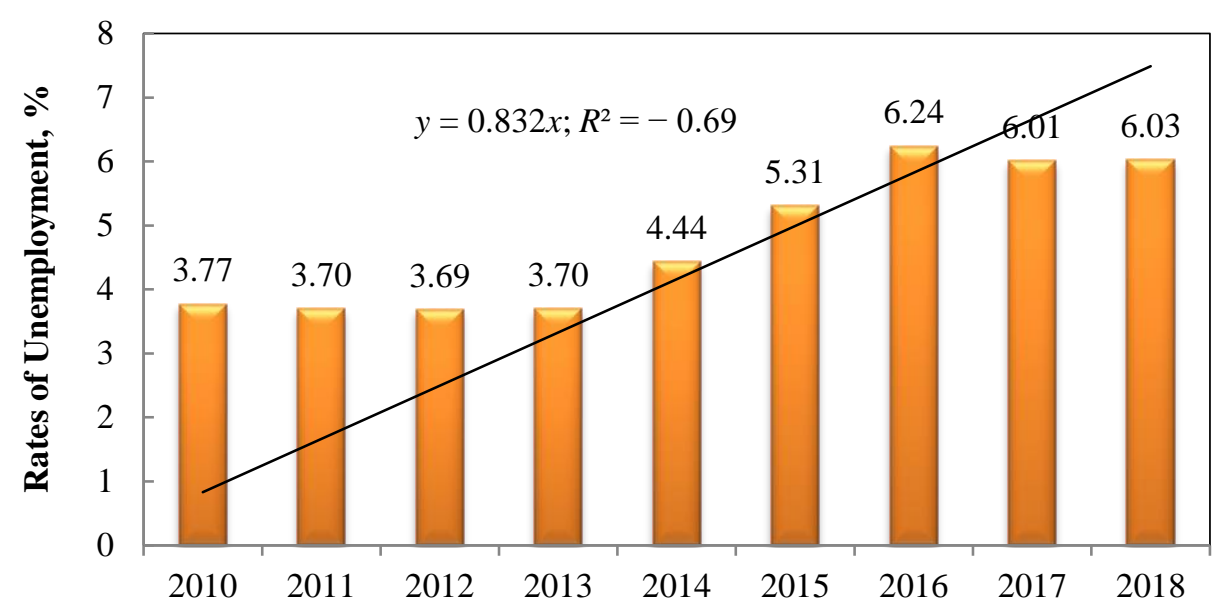

The Years of Rated Unemployment

Fig. 3. The Unemployment Rate in Nigeria from 1999-2018 (developed by the authors, based on International Labour Organization) 
From Table 3, the unemployment rate provides data for Nigeria from 1991 to 2018 but Fig. 3 shows the unemployment rate from 2010 to 2018 by the decision of the authors. The average value for Nigeria during the period from 2010 to 2018 was $4.77 \%$ with a minimum of $3.69 \%$ in 2012 and a maximum of $6.24 \%$ in 2016 . Nigeria ranks $83^{\text {rd }}$ out of 181 countries in the world in the unemployment rating.

\subsection{Tertiary Institutions: Centres for Entrepreneurial Training and Education}

There could have been no better milieu to begin the vision of entrepreneurship if it were not in an educational environment. This is the fundamental reason why the Nigerian government through the National Universities Commission establishes entrepreneurship study centres at the Nigerian Universities' campuses. The government adopted that the universities and other higher schools of learning should serve as a training environment for learning, growth and development of sustainable entrepreneurial education for the undergraduates. The idea is to provide facilities and expertise that will propel the growth and development of small and medium enterprises (SMEs) through sustainable quality, effective and dynamic entrepreneurial schooling and support. While the study maintains its focus on the core meaning of entrepreneurship, which is anchored on, capacity and willingness to develop, organize and manage a business venture along with any of its risks in order to make a profit (Yetison, et al., 2015; Katila, Chen, \& Piezunka, 2012), the enabling environment for the entrepreneurship must be adequate and friendly with sustainable equipment for development. Essentially, the environment for development should, among other things, promote the culture of entrepreneurship among university students and address the problem that will eradicate poverty and eliminate unemployment among the graduates. The combination of training and adequate environment would help students acquire entrepreneurial skills for job creation and provide them with ample opportunities that will improve their productive capacities for enterprise development skills. In line with the National Universities Commission directive, the Centre for Entrepreneurial Studies (CES) was proposed at all the universities in Nigeria (Akintayo, 2014).

\subsection{Importance of Education and Training in Entrepreneurial Development}

Education is a means of transferring knowledge from one person to another or a group of persons. According to Manish and Sunil (2015), education has been the axle for social, economic and political transformation in all societies. They observed that it acts as an integrative force in the society, imparting values that foster individual excellence, social cohesion and national development. Recognising the importance of education in national development, the policymakers (European Commission, 2006; UNESCO, 2013; Kapranos, 2014) have placed an unprecedented focus on a recently identified concept in the field of education across all levels named as entrepreneurial skill development through education. Highlighting the importance of promoting entrepreneurship education in tertiary institution, Ademiluyi (2007) affirms that it addresses some sociopsychological problems and delinquency that arise from joblessness. Michelacci and Schivardi (2016) examined relationships between an entrepreneur's earnings 
and education level. Their finding shows that the higher the education levels of an entrepreneur, the greater the earnings.

In another study David et al. (2010) noted that "entrepreneurship had been a strategic driver for creating a job, increasing income, facilitating the adjustment to economic change and supporting competitiveness at the local level"; however, "to foster entrepreneurship at the regional level, there is a need to strengthen the role played by entrepreneurial universities, especially, in terms of entrepreneurship education oriented towards innovation and endogenous growth". Robert and Robert (2011) examined the role of universities in education and knowledge creation; they remarked that their roles were apparent and essential in economic growth. Their observation shows that university education improves the skills in the labour force through propagating existing and new knowledge using a traditional teaching approach. Piperopoulos and Dimov (2015) believe that "education is necessary to provide a general understanding of entrepreneurship in the area of development of the student's skills and abilities. On the other hand, if training is more practiceoriented, students will have a more complete understanding of entrepreneurship". Universities, especially research universities, do a lot more than teaching. Gielnik et al. (2015) argued that achieving the goal of entrepreneurial education could assume a 'practice-oriented' approach aimed at recreating in an educational setting the context, in which entrepreneurs learn.

\subsection{Real Estate Entrepreneurial Education at Nigeria's Accredited Tertiary Institutions}

The focus of this study is to examine entrepreneurship training and education in estate management (real estate). Estate management is a prospective and fertile area where entrepreneurship can be very profitable for innovation and job creation. Estate Surveyors and Valuers Registration Board (ESVARBON), National Universities Commission (NUC) and National Board for Technical Education (NBTE) are the three major statutory bodies legislated with the responsibilities to monitor the education, training and practice of estate surveying and valuation profession in Nigeria. The National Universities Commission and NBTE are responsible for the monitoring of the curriculum of education of undergraduates at the universities for all courses while NBTE monitors the curriculum for polytechnics and colleges of technology. The Estate Surveyors and Valuers Registration Board of Nigeria is concerned with the education and training of undergraduates and postgraduates of tertiary institutions running estate management at the universities, polytechnics and colleges of technology in Nigeria. They are responsible for the accreditation of the tertiary institution and the recognition of the certificates of the graduating students. If any of the tertiary institutions are not accredited, such a school will not be licensed to admit candidates for the number of years of the denial. Tables 4 and 5 are the statuses of accredited universities, polytechnics and colleges of technology for estate management and valuation in Nigeria by Estate Surveyors Valuers Registration Board of Nigeria (2019a, b).

Some Nigerian Universities, including other tertiary institutions, run Real Estate program known as Estate Management, but most recently some schools have 
adopted the nomenclature - estate management and valuation. Estate surveying and valuation profession offer several opportunities for entrepreneurship given that the demand from the society is very high and innovation is required to match the demand. "Real estate is property consisting of land and the buildings on it, along with its natural resources such as crops, minerals or water; immovable property of this nature; an interest vested in this (also) item of real property, (more generally) buildings or housing in general" (Alfred \& Jerome, 1985; Cheryl, 2006). Real estate business involves purchase, sales and renting of land and buildings (James 2019 \& Kimberley 2019). Some of the Universities in Nigeria accredited to run estate management programmes are shown at Table 4.

Table 4. Accredited Universities for Estate Management Courses (Estate Surveyors and Valuers Registration Board of Nigeria, 2019b)

\begin{tabular}{|l|l|c|l|}
\hline S/No & Names of Universities & $\begin{array}{c}\text { No. of } \\
\text { Years } \\
\text { granted }\end{array}$ & Effective Academic Year \\
\hline 1 & University of Nigeria, Nsukka & 5 & $2014 / 2015-2018 / 2019$ \\
\hline 2 & Obafemi Awolowo University, Ile-Ife & 5 & $2014 / 2015-2018 / 2019$ \\
\hline 3 & University of Lagos, Akoka & 5 & $2012 / 2013-2016 / 2017$ \\
\hline 4 & Abia State University, Uturu & 5 & $2013 / 2014-2017 / 2018$ \\
\hline 5 & Fed University of Technology, Akure & 5 & $2015 / 2016-2019 / 2020$ \\
\hline 6 & Fed. University of Technology, Minna & 4 & $2013 / 2014-2016 / 2017$ \\
\hline 7 & River State University of Science and & 5 & $2015 / 2016-2019 / 2020$ \\
\hline 8 & Imochnology, Port Harcourt & 4 & $2014 / 2015-2017 / 2018$ \\
\hline 9 & Nnamdi Azikiwe University, Awka & 5 & $2012 / 2013-2016 / 2017$ \\
\hline 10 & University of Uyo, Uyo & 5 & $2014 / 2015-2018 / 2019$ \\
\hline 11 & Enugu State University of Science and & 5 & $2010 / 2011-2015 / 2016$ \\
\hline 12 & Technology & & \\
\hline 13 & Covenant University, Ota & 5 & $2012 / 2013-2016 / 2017$ \\
\hline 14 & Cross River University of Technology & 4 & $2015 / 2016-2018 / 2019$ \\
\hline 15 & Joseph Ayo Babalola University & 4 & $2011 / 2012-2014 / 2015$ \\
\hline 16 & Bells University of Technology, Ota & 4 & $2012 / 2013-2014 / 2015$ \\
\hline 17 & Caritas University, Enugu & 4 & $2013 / 2014-2016 / 2017$ \\
\hline 18 & Kaduna State University & 4 & $2015 / 2015-2017 / 2018$ \\
\hline 19 & University of Ilorin & 3 & $2017 / 2018-2018 / 2019$ \\
\hline 20 & Bayero University, Kano & 3 & $2017 / 2018-2020 / 2021$ \\
\hline & & & \\
\hline
\end{tabular}

Table 4 shows the number of Universities that offers Estate Management courses that were accredited. The accreditation of the Universities shown in the table implies that they are qualified to run Estate Management courses based on the Regulatory Board's assessment. In the assessment, facilities and staff qualifications were considered. The total number of universities approved by the Estate Surveyors and Valuers Registration Board of Nigeria (ESVARBON) is twenty (20) Universities as listed in Table 4. The twenty (20) Universities are among the one hundred and seventy-four (174) Universities approved by National Universities Commission (NUC) of Nigeria. 
Table 5 shows the number of Polytechnics and Colleges of Technology in Nigeria that were approved to run the programme of Estate Management. Polytechnics and Colleges of Technology offer Diploma Certificates which are categorised into National Diploma (ND) and Higher National Diploma (HND). National Diploma is two academic sessions while the Higher National Diploma is four academic sessions excluding one-year Industrial Training (IT) experience.

Table 5. Accredited Polytechnics and Colleges of Technology for Estate Management Courses (Estate Surveyors and Valuers Registration Board of Nigeria, 2019a)

\begin{tabular}{|l|l|c|c|}
\hline S/No & $\begin{array}{l}\text { Names of Polytechnics and Colleges of } \\
\text { Technology }\end{array}$ & $\begin{array}{c}\text { No. of } \\
\text { Years } \\
\text { granted }\end{array}$ & $\begin{array}{c}\text { Effective Academic } \\
\text { Year }\end{array}$ \\
\hline 1 & Yaba College of Technology, Yaba, Lagos & 5 & $2012 / 2013-2016 / 2017$ \\
\hline 2 & Federal Polytechnic, Auchi & 5 & $2012 / 2013-2016 / 2017$ \\
\hline 3 & The Polytechnic, Kaduna & 5 & $2015 / 2016-2019 / 2020$ \\
\hline 4 & Federal Polytechnic, Oko, Anambra State & 4 & $2014 / 2015-2017 / 2018$ \\
\hline 5 & $\begin{array}{l}\text { Kwara State Polytechnic, Ilorin, Kwara } \\
\text { State }\end{array}$ & 3 & $2015 / 2016-2017 / 2018$ \\
\hline 6 & Federal Polytechnic, Bauchi & 4 & $2010 / 2011-2013 / 2014$ \\
\hline 7 & Federal Polytechnic, Ibadan & 5 & $2015 / 2016-2019 / 2020$ \\
\hline 8 & Moshood Abiola Polytechnic, Abeokuta & 5 & $2015 / 2016-2019 / 2020$ \\
\hline 9 & $\begin{array}{l}\text { Osun State College of Technology, Esa } \\
\text { Oke }\end{array}$ & 4 & $2011 / 2012-2014 / 2015$ \\
\hline 10 & Federal Polytechnic, Nasarawa & 5 & $2015 / 2016-2019 / 2020$ \\
\hline 11 & Federal Polytechnic, Bida & 3 & $2012 / 2013-2014 / 2015$ \\
\hline 12 & Federal Polytechnic, Ilaro, Ogun State & 5 & $2012 / 2013-2016 / 2017$ \\
\hline 13 & Rufus Giwa Poly, Owo-Ondo State & 5 & $2010 / 2011-2014 / 2015$ \\
\hline 14 & Federal Polytechnic, Nekede, Imo State & 4 & $2014 / 2015-2017 / 2018$ \\
\hline 15 & Federal Polytechnic, Idah, Kogi State & 5 & $2011 / 2012-2015 / 2016$ \\
\hline 16 & Lagos State Polytechnic, Ikorodu, Lagos & 4 & $2011 / 2012-2014 / 2015$ \\
\hline 17 & Abia State Polytechnic, Aba, Abia State & 4 & $2015 / 2016-2018 / 2019$ \\
\hline 18 & Federal Polytechnic, Damaturu, Yobe State & 3 & $2010 / 2011-2012 / 2013$ \\
\hline 19 & Ken Saro-Wiwa Polytechnic, Bori & 4 & $2014 / 2015-2017 / 2018$ \\
\hline 20 & Federal Polytechnic, Ede, Osun State & 4 & $2011 / 2012-2014 / 2015$ \\
\hline 21 & Akwa Ibom State Polytechnic & 3 & $2014 / 2015-2016 / 2017$ \\
\hline 22 & Akanu Ibiam Federal Polytechnic, Afikpo & 4 & $2014 / 2015-2017 / 2018$ \\
\hline 23 & $\begin{array}{l}\text { Institute of Management and Technology, } \\
\text { Enugu }\end{array}$ & 3 & $2015 / 2016-2017 / 2018$ \\
\hline 24 & Oke Ogun Polytechnic, Saki & 3 & $2017 / 2018-2020 / 2021$ \\
\hline 25 & Federal Polytechnic, Ado-Ekiti & 5 & $2016 / 2017-2020 / 2021$ \\
\hline 26 & Imo State Polytechnic, Umuagwo & 3 & $2016 / 2017-2019 / 2020$ \\
\hline 27 & Abubakar Tatari Ali Polytechnic, Bauchi & & \\
\hline & & & \\
\hline
\end{tabular}

Table 5 shows twenty-seven (27) Polytechnics and Colleges of Technology that are approved by Estate Surveyors and Valuers Registration Board of Nigeria (2019a) to run Estate Management programme. There are about one hundred and thirteen (113) Polytechnics and Colleges of Technology in Nigeria (National Board for Technical Education, 2019) and only twenty-seven of them offer Estate Management programme. 


\subsection{The Contribution of Real Estate Entrepreneurship to Nation's Gross Domestic Product}

The Nigerian Real Estate Guide (2015) reveals the prospectiveness of the Nigerian Real Estate Sector and how it recorded steady and consistent growth over the last eight years. "This has made it become one of the greatest contributors to the nation's rebased gross domestic product (GDP) from the non-oil sector by the contributions of $8.03 \%$ and $11 \%$ in 2013 and 2014, respectively. The market, which was valued at approximately N 6.5 trillion, was estimated to have grown to an average of $10 \%$ over the subsequent years. The major growth drivers in the sector have been credited to an increased inflow of foreign investment (especially from South Africa, MEA and the United States); increased institutional investment from local companies, including pension fund administrators (PFAs) and Mutual Funds; the growing population of High Net worth individuals; and the targeted intervention of the Federal Government in the housing finance sector" (Taiwo \& Delia, 2017).

Daniel (2019) stated that the real estate sector was among Nigeria's biggest GDP contributors in the national economy. He adduced that the construction and real estate sectors picked up massively from the economic meltdown that hit the country in 2016 to become key contributors to the country's economic recovery. The record of National Bureau of Statistics (2019) showed that "from the Gross Domestic Product (GDP) figures of the second quarter of 2018 that Nigeria, which slipped into recession in 2016, was rescued in 2017 due to economic growth driven by the non-oil sector. The report revealed that the non-oil sector expanded by $2.05 \%$ and added $91.45 \%$ to the nation's GDP compared to $90.96 \%$ recorded in Q2 2017". Among the sectors that led the expansion in the real term were the construction and slightly real estate sectors, including cement and wood product manufacturing. According to the report, the construction sector grew by $7.66 \%$ in Q2 2018 from $-1.54 \%$ in Q1 2018 and $4.14 \%$ in Q4 2017. Although the real estate sector contracted by $-3.88 \%$ in Q2 2018 from $-9.40 \%$ in Q1 2018, it was higher than $5.87 \%$ reported in the preceding quarter. The analysis showed that the growth in the sectors could be attributed partly to the availability of foreign exchange and the improving economic climate, which encouraged investment in the country in general. The findings also demonstrated that there was a flurry of road construction and rehabilitation, rail, infrastructure and other capital projects that year, which saw the Federal Government pumping billions into them.

\subsection{The reward for Real Estate Entrepreneurial Education and Training}

There are multifaceted opportunities in the real estate sector of the economy given that adequate entrepreneurial training and education are provided to the students while in school to equip them for the opportunities outside the academia. When the opportunities are created and the skills are lacking, it would be another phase of the crisis. Reports have shown that some real estate opportunities abound, expecting graduates with entrepreneurial ingenuity to grab them (Real Estate Guide, 2015; Daniel, 2018). Since 2018, strategic collaboration has been under consideration between the private sector and government aimed at addressing the 
housing requirements of the country. In the preceding months, for instance, the Federal Housing Authority (FHA) performed a ground-breaking ceremony of one of its new flagship projects called the Diaspora City, which was mapped in seven states of Nigeria. An instance of 700 hectares of land, which was acquired at Abuja's Maitama Extension for the Abuja section of the project, could be rewarding for a real estate entrepreneur who is professionally skilled in the real estate discipline. Similarly, the Federal Mortgage Bank of Nigeria (FMBN) in conjunction with labour and trade unions planned a ground-breaking ceremony of the first phase of an affordable housing scheme for workers, which was planned to deliver 2800 housing units in 14 sites across the country. The private sector has been active in the real estate market with the resumption of work at one of the most anticipated high-end developments in Abuja. All these projects require a knowledgeable real estate entrepreneur who had gone through education and training to participate in the project delivery. To maintain the existing professional profile, the Real Estate Guide (2015) revealed opportunities that could inspire more skilled workers who are more adaptable and able to learn and apply new skills as economies change and grow and, in the process, create new jobs. Skilled workers also develop themselves to become more resourceful entrepreneurs, find new businesses, and become important drivers of innovation and job creation.

\section{METHODS AND PROCEDURES}

\subsection{The Study Location}

The study was conducted in Nigeria and specifically, Uyo in Akwa Ibom State. According to Akwa Ibom State Government (AKSG) (2012), Akwa Ibom is one of the 36 states of Nigeria. David (2018) noted that "the State is located in the SouthSouth geopolitical zone and it is bordered on the east by Cross River State, on the west by Rivers State and Abia State, and on the south by the Atlantic Ocean and the southernmost tip of Cross River State".

The focus area of the study was the University of Uyo and particularly students of the Department of Estate Management. Awajiowa (2016) revealed that University of Uyo was formerly known as the University of Cross River State and it is located in Uyo, capital of Akwa Ibom State, Nigeria. Awajiowa recounted that on October 1, 1991, the Federal Government of Nigeria established it as a federal university and the name was changed to be University of Uyo. According to University of Uyo (2019), the "university has 12 faculties, the postgraduate school, and the school of continuing education. It operates from four campuses: The Main Campus that accommodates Parts of Central Administration, Faculties of Engineering and Natural and Applied Sciences, International Centre for Energy and Environmental Sustainability Research (ICEESR), the Postgraduate School and recently the Faculty of Agriculture; the Town Campus accommodates Faculties of Arts, Education, Social Sciences, Pharmacy. Then the Annex Campus is the domain of the Faculties of Business Administration, Law, Environmental Studies and General Studies. The Ime Umana Campus, Ediene Abak, is intended for the PreDegree, JUPEB and other special courses". 


\subsection{Methodology}

The paper is a descriptive study involving a case study of the performance of estate management students in the subject areas of both entrepreneurial studies and subject-related courses. The study examined the performance of the students in entrepreneurial studies and other related courses to ascertain their willingness to become entrepreneurs in the real estate sector. Five years of the academic studies were evaluated starting from $2014 / 2015$ to $2018 / 2019$. The academic performance of the students using their scores in the examinations of the related subjects was adopted to assess their performance. The selected courses used for the assessment are presented in the table below.

\subsection{Findings of the Study}

The mean scores of the students and the mean scores of the students' willingness to adhere to real estate entrepreneurship education and training are shown at Table 6 and Figure 6 respectively.

Table 6. The Mean Scores of the Students (\%) (developed by the authors)

\begin{tabular}{|l|c|c|c|c|c|}
\hline Courses/Year & $\mathbf{2 0 1 4 / 2 0 1 5}$ & $\mathbf{2 0 1 5 / 2 0 1 6}$ & $\mathbf{2 0 1 6 / 2 0 1 7}$ & $\mathbf{2 0 1 7 / 2 0 1 8}$ & $\mathbf{2 0 1 8 / 2 0 1 9}$ \\
\hline Entrepreneurs & 63 & 55 & 70 & 68 & 54 \\
\hline Mathematics & 51 & 49 & 56 & 58 & 60 \\
\hline English & 58 & 67 & 68 & 74 & 63 \\
\hline Philosophy \& Logic & 56 & 53 & 48 & 65 & 54 \\
\hline $\begin{array}{l}\text { Computer } \\
\text { Application }\end{array}$ & 67 & 69 & 58 & 62 & 58 \\
\hline Valuations & 56 & 48 & 53 & 47 & 58 \\
\hline Economics & 53 & 50 & 55 & 58 & 62 \\
\hline Building Services & 63 & 54 & 56 & 61 & 58 \\
\hline $\begin{array}{l}\text { Investment } \\
\text { Appraisals }\end{array}$ & 61 & 66 & 54 & 57 & 45 \\
\hline $\begin{array}{l}\text { Computer-Aided } \\
\text { Design }\end{array}$ & 42 & 45 & 47 & 41 & 35 \\
\hline Housing Process & 56 & 55 & 55 & 53 & 57 \\
\hline $\begin{array}{l}\text { Facilities } \\
\text { Management }\end{array}$ & 61 & 57 & 63 & 71 & 68 \\
\hline
\end{tabular}




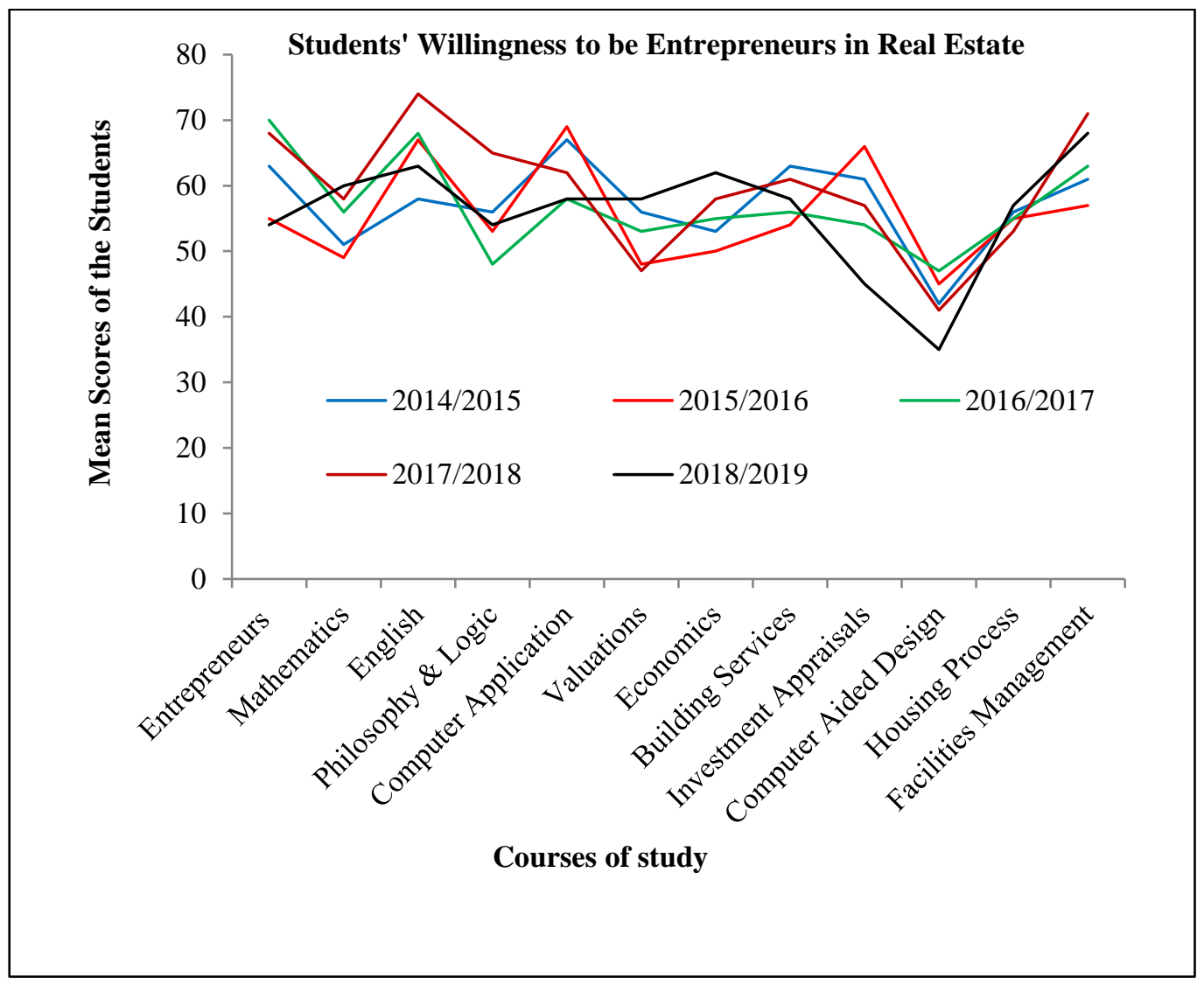

Fig. 4. The mean scores of the students' willingness to adhere to real estate entrepreneurship education and training (developed by the authors)

Table 6 above displays the students' willingness to engage in entrepreneurial training and education in the real estate sector after graduation from the university. Five (5) academic years were assessed and the courses considered were twelve (12). The mean performance of the students was encouraging. The grading of the students' scores is as follows: $\mathrm{A}=70-100 ; \mathrm{B}=60-69 ; \mathrm{C}=50-59 ; \mathrm{D}=45-49$; $\mathrm{E}=40-44$; and $\mathrm{F}=0-39$. The performance of the students was mostly between $\mathrm{C}$ and A grades. Students' performance in entrepreneurial studies based on their mean scores was in the region of B grade (62\%). Students' performance was above average in most of all the courses except in mathematics and computer-aided design. It is believed that when the factors responsible for the low performance of the students in those areas are addressed, the performance of the students will be improved.

\section{CONCLUSION}

The study concludes that the perception and responses of undergraduates of Estate Management and Valuation on entrepreneurship training and education were above $50 \%$. The entrepreneurship course for the five sessions observed shows that the students" mean scores were between $54 \%$ which is " $\mathrm{C}$ " grade in NUC rating 
scale and $70 \%$ which is " $\mathrm{A}$ " grade in NUC rating scale. The overall mean score for the entrepreneurial course was $62 \%$ which is " $\mathrm{B}$ " grade in the NUC rating scale. By this result, it could be concluded that the perception and responses of the students to entrepreneurship education were high, though not optimal. This performance also informs that the students were able to prevail over the challenges in their courses of study and could overcome the unemployment problem in the society after graduating.

\section{The Implication of the Study}

The achievement of the real estate entrepreneurship training and education at tertiary institutions can be a source of remedy to unemployment in Nigeria for estate management graduating students. This can go a long way to increase the employment rate in Nigeria, as many graduating entrepreneurs will be available in the labour market, thereby increasing employment opportunities of other unemployed graduates and labour hunters.

\section{Recommendations}

This study presents the following recommendations:

1. Real estate training and education for entrepreneurship should be given sufficient attention at the tertiary institutions in Nigeria for a more prospective turn out of creative and innovative graduates.

2. The learning environment is deficient with adequate facilities in terms of classrooms, studios and other facilitating types of equipment; and for this reason, this paper strongly recommends the development of enabling training and educational environment for entrepreneurship.

3. Adequate and qualified teaching and training staff should be employed and engaged in the teaching and training of the undergraduates for sustainable selfreliant skill acquisition to forestall unemployment problems ravaging the nation.

4. Educationists and trainers who are creative and ingenious with suitable academic qualification should be employed to inculcate their expertise in the students.

5. Motivation and encouragement should be given to the educationists, trainers and the students for the success of the vision.

\section{ACKNOWLEDGEMENT}

On behalf of the co-authors of this paper, Paul Anih wishes to express his sincere thanks to everyone who has made the publication of this paper possible. I appreciate the contributions and the team spirit exhibited by the co-authors (Dr Chicheta Nissi \& Miss Uduakobong Akpan) in several ways that made this publication possible. I am thankful to the authors of various articles cited in this work without which the completion of this work would not have been made possible. 


\section{REFERENCES}

Adam, H. (2019). Entrepreneur. Investopedia. Retrieved from https://www.investopedia.com/ July $2,2019$.

Adekunle, S. O. \& David, J. K. (2014). Entrepreneurship Education in Nigerian Universities: A Tool for National Transformation. Asia Pacific Journal of Educators and Education, 29, 155-175.

Ademiluyi, L. F. (2007) Business Competencies Needed for Effective Entrepreneurship as Perceived by Fresh Graduates. Business Education Journal 1(1), 18-29.

Adeyemo, I. (2018). 16 Million Unemployed in Nigeria in 2017. Third Quarter-National Bureau of Statistics. RetrievedApril 4, 2019, from http.www.Premiumtimesng.com.

Akwa Ibom State Government. (2012). About Akwa Ibom State: Geography \& Location. Retrieved from https://www.aksgonline.com/about_geography.html

Akintayo E. (2014). National Universities Commission Approves Integration of Entrepreneurship Program in Varsity Curriculum. Vanguard News. Retrieved July 10, 2019, from https://www.Vanguardngr.com

Alfred, A. R., \& Jerome, D. (1985). Real Estate Principles and Practices. New Jersey. PrenticeHall.

Almeida, F., De Paula, N., \& Pessali, H. (2014). Institutional Entrepreneurship in building the Brazilian market of functional yoghurts. British Food Journal, 116, 2-5. https://doi.org/10.1108/BFJ-02-2012-0028

Awajiowa, I. (2016). History of University of Uyo. Retrieved from https://www.uniuyo.edu.ng

Business Dictionary (2015). Business Dictionary definition. Retrieved July 8, 2019, fromhttps://www.business dictionary.com.

Cheryl, P. N. (2006). Texas Principles of Real Estate Parts I \& II. Chicago. Dearborn.

Daniel A. (2018). Construction, real estate among Nigeria's biggest GDP contributors - Data. DailyTrust Newspaper. Retrieved July 8, 2019, from https://www.dailytrust.com.ng

David, E. (2018). On Governance, Nigeria, Akwa Ibom, and Roads. What Next? Retrieved from: https://medium. com/@Davidedet_/on-governance-nigeria-akwa-ibom-and-roads-what-nextd1a7e336acc0

David S., João L., Mário R., \& Friederike W. (2010). The Theory and Practice of Entrepreneurship: Frontiers in European Entrepreneurship Research. California. Edwardelgar.

Estate Surveyors and Valuers Registration Board of Nigeria. (2019a). Polytechnics Accreditation. Retrieved from: https://www.Estate Surveyors and Valuers Registration Board of Nigeria.gov.ng/Accredited-Institutions /Accredited-Polytechnics

Estate Surveyors and Valuers Registration Board of Nigeria. (2019b). Universities Accreditation. Retrieved from: https://www.Estate Surveyors and Valuers Registration Board of Nigeria.gov.ng/Accredited-Institutions /Accredited-Universities

European Commission. (2006). Entrepreneurship education in Europe: fostering entrepreneurial mindsets through education and learning. Brussels, 26-27 October. Retrieved from http://ec.europa.eu/enterprise/policies/SPIJE

Falola, F. (2009). National Universities Commission and National Board for Technical Education (NBTE) lauded over the introduction of entrepreneurial studies. Sunday punch p.50.

Gielnik, M. M., et al. (2015). Action and Action-regulation in Entrepreneurship: Evaluating a Student Training for Promoting Entrepreneurship. Academy of Management Learning \& Education, 14(1): 69-94. https://doi.org/10.5465/amle.2012.0107

International Labour Organization (2017). Unemployment, total (\% of total labor force) (national estimate), ILOSTAT database. Data retrieved in August, 2019: https://www.indexmundi.com/facts/indicators/SL.UEM.TOTL.NE.ZS

James C. (2019). What Is Real Estate? Investopedia.com. Retrieved July 01, 2019: https://www.investopedia.com/

Jennifer O., Nick C., and Caroline A. (2017). Education System Profiles: Education in Nigeria. Retrieved from: https://wenr.wes.org/2017/03/education-in-nigeria

Kapranos, P. (2014). Teaching Transferable Skills to Doctoral Level Engineers - The Challenge and the Solutions. Open Journal of Social Sciences, 2(5), 66-75. https://doi.org/10.4236/jss.2014.25014 
Katila, R., Chen, E. L., \& Piezunka, H. (2012). All the right moves: How entrepreneurial firms compete effectively. Strategic Entrepreneurship Journal, 6(2): 116-132. https://doi.org/10.1002/sej.1130

Khan, F., Munir, K., \& Willmott, H. (2007). A Dark Side of Institutional Entrepreneurship: Soccer Balls, Child Labour, and Postcolonial Impoverishment. Organization Studies, 28(7): 1055-1077. https://doi.org/10.1177/0170840607078114

Kimberley, A. (2019). Real Estate, What It Is and How It Works. Retrieved on July 01, 2019: https://www.thebalance.com/real-estate-what-it-is-and-how-it-works-3305882

Levy, D., \& Scully, M. (2007). The institutional entrepreneur as a modern prince: The strategic face of power in contested fields. Organization Studies. 28(7): 971-991. https://doi.org/10.1177/0170840607078109

Manish, K. G., \& Sunil, K. S. (2015). Entrepreneurship Education: Concept, Characteristics, and Implications for Teacher Education. Banaras. Shaikshik Parisamvad Journal of Education SPIJE, 5(1): 21-35.

Michelacci, C., \& Schivardi, F., (2016). Are They All Like Bill, Mark, and Steve? The Education Premium for Entrepreneurs. EIEF Working Papers Series 1612, Einaudi Institute for Economics and Finance (EIEF), Revised Sep 2017. https://doi.org/10.2139/ssrn.3035938

National Board for Technical Education. (2019). List of Polytechnics and Colleges of Education in Nigeria. Retrieved from: https://www.nbte.gov.ng/inst_01.html

National Bureau of Statistics (2017). Labour Force Statistics Vol. 1: Unemployment and Underemployment Report. Retrieved from: https://www.proshareng.com/news/Nigeria

National Bureau of Statistics (2019). Nigerian Gross Domestic Product Report (Q1 2019). Retrieved from: http://www.nigerianstat.gov.ng.

National Universities Commission (2019). The Nigerian Universities approved to run Undergraduate and Post Graduate Programmes in Nigeria. Retrieved from: http://nuc.edu.ng/

Nigerian Real Estate Guide (2015). The Real Estate Sector. Retrieved July 5, 2019 from: https://www.lagos-nigeria-real-estate-investing-guide.com/real-estate-guide.html

Piperopoulos, P., \& Dimov, D. (2015). Burst Bubbles or Build Steam? Entrepreneurship Education, Entrepreneurial Self-Efficacy, and Entrepreneurial Intentions. Journal of Small Business Management, 53(4): 970-985. https://doi.org/10.1111/jsbm.12116

Kapranos, P. (2014). Teaching Transferable Skills to Doctoral Level Engineers - The Challenge and the Solutions. Open Journal of Social Sciences, 2(5):66-75.

Robert E. L. \& Robert C. D. (2011). Rules for Growth through Universities and Economic Growth: The Importance of Academic Entrepreneurship. Rockhill Road, Kansas City, Missouri: Ewing Marion publishers.

Taiwo, O. \& Delia, A. (2017). Economic and fiscal implications of Nigeria have rebased GDP. PwC Nigeria. Retrieved from: https://www.pwc.com/ng/en/publications/gross-domestic-productdoes-size-really-matter.html [August 1, 2019]

UBEC. (2012). Universal Basic Education Commission. Retrieved 30 June, 2019 from: https://www.ubec.gov.ng/

UNESCO. (2013). Rethinking Education in a changing world. Retrieved from: http://www.unesco.org/new/en/education/themes/leading-the-international-agenda/rethinkingeducation/ in April 20, 2015

University of Uyo. (2019). History of University of Uyo. Retrieved from: https://www.uniuyo.edu.ng

World Bank. (2019). Nigeria: Unemployment rate. Retrieved from: https://www.theglobaleconomy.com/ Nigeria/Unemployment rate/

World Education Services (WES). (2017). Education System Profiles: Education in Nigeria. Retrieved on August 13, 2019 from: https://wenr.wes.org/2017/03/education-in-nigeria

Yetisen, A. K., Volpatti, L. R., Coskun, A. F., Cho, S., Kamrani, E., Butt, H., Khademhos, A., \& Yun, S. H. (2015). Entrepreneurship. Lab on a Chip. 15(18): 3638-3660. https://doi.org/10.1039/C5LC00577A 


\section{AUTHORS' SHORT BIOGRAPHIES}

Paul Chuks Anih is a Lecturer at the Department of Estate Management of the University of Uyo, Nigeria. He received the $\mathrm{Ph}$. D. degree in Estate Management from the University of Nigeria, Nsukka. He specializes in facility/property management and environmental valuation.

Dr. Anih is currently a Senior Lecturer with the University of Uyo, Nigeria. He has articles in both international and local journals. He has also presented papers in both local and international (Nairobi) conferences.

He is an Associate Member of the Nigerian Institution of Estate Surveyors and Valuers (NIESV). The author has two awards to his credit: The Award of Excellence for examination officer and the Award of Recognition for paper presentation at NIESV National Conference, 2019.

E-mail: paulanih@uniuyo.edu.ng

ORCID iD: https://orcid.org/0000-0003-2636-9511

Dr. (Mrs.) Nissi Chicheta Francis holds a Bachelor of Science in Estate Management from the University of Uyo, Nigeria. She equally holds Master and Doctor of Philosophy Degrees in Estate Management from Nnamdi Azikiwe University Awka, Nigeria.

Her areas of interest are real estate investment analysis/valuation and property management. Dr. (Mrs.) Nissi is an Associate Member of the Nigerian Institution of Estate Surveyors and Valuers, as well as a Registered Surveyor and Valuer of the Estate Surveyors and Valuers Registration Board of Nigeria. Dr. (Mrs.) Nissi is a Senior Lecturer at the Department of Estate Management of the University of Uyo.

E-mail: nissiestate22@gmail.com

Uduakobong Enamidem Akpan is a Lecturer at the Department of Estate Management, the University of Uyo, Uyo, Nigeria. She holds a Bachelor degree in Estate Management from the University of Uyo and a Master degree in Estate Management from the Obafemi Awolowo University, Ile-Ife. She is currently a doctoral student at the same university. Her areas of research include real estate investment analysis, real estate development appraisal, valuation and real estate education.

E-mail: uduakobongakpan@uniuyo.edu.ng 